○津田潤子、菅原一真、金川英寿、御厨剛史、山下裕司

山口大学大学院 医学系研究科 耳鼻咽喉科学分野

【目的】糖尿病に難聴が合併することは以前から指摘されるが、機序については多くは解明できていない。2 型糖尿病モ デルマウス TSOD を用いて加齢に伴う聴覚の変化を検討した。【方法】TSOD および対象動物としてTSNO マウスを用い た。3、5、8、10、13力月齢で、体重、血糖值および聴覚の評価として聴性脳幹反応（ABR）閾值を測定した。側頭骨を 摘出し組織学的に検討した。【結果】体重はいずれの月齢でも有意に高值を示した。血糖值は $3 、 5 、 8$ 月齢では有意に 高值を示したが10、13カ月齢では有意差は得られなかった。ABR 閾值は $3 、 5$ 月齢では両マウスに明らかな差を認めな かったが 8 カ月齢より有意に上昇した。組織学的には13力月齢で蝸牛軸の血管内皮の肥厚を認めた。【考察】TSODマウス はヒトの肥満型糖尿病に類似した病態を発症し、過食、内臓脂肪蓄積型の重度の肥満、高血糖、高脂血症が認められメタボ リックシンドロームモデルとして注目される。TSOD は加齢に伴い聴覚の有意な低下を認め、組織学的には血管壁の変化を 認めた。

130 マウス単一糸球に属する僧房細胞群の異なる匂い応答

○菊田＼cjkstart周(12)、山岨達也 ${ }^{11} 、$ Wei R. Chen ${ }^{2}$

東京大学 医学部 耳鼻咽喉科 ${ }^{12} 、$ テキース大学 医学部 ヒューストン 神経生物 ${ }^{2}$

はじめに

同じ匂い分子受容体を発現する嗅神経は嗅球内の同じ糸球に軸索投射する。したがって同じ糸球に接続する嗅球の出力細 胞群（糸球モジュール）は嗅神経から同質の匂い情報を受け取る。糸球モジュール内での匂い応答表現を明らかにするため に、糸球モジュールに接続する細胞群を染色し、機能イメージング解析を行った。

方法

糸球を可視化させたマウスを使用し、電気穿孔法によってカルシウム感受性蛍光色素を単一系球に注入、僧房細胞を染色 した。僧房細胞の嗅球内での広がりならびに匂い刺激に対する応答を 2 光子励起顕微鏡で観察した。

結果

1. 僧房細胞は所属糸球の範囲を越えて広範囲に分布していた。

2. 近傍に位置する僧房細胞同士は似た応答選択性を示すが、離れた僧房細胞同士は異なる応答選択性を示した。 まとめ

単一系球で表現された包い情報は、僧房細胞では必ずしも同一に表現されていなかった。個々の僧房細胞は、顆粒細胞と の相互作用の相違によって異なる匂い応答を示し、匂い情報の異なる側面を嗅皮質に伝達していると予想する。

\title{
131 好酸球性副鼻腔炎鼻茸におけるマクロファージについての検討
}

○楠 威志、小野倫嗣、齋藤達矢、池田勝久

順天堂大学 医学部 耳鼻咽喉科学講座

背景と目的：近年、重度の喘息には好酸球のほかマクロファージ、好中球の増加と、これらの産生に関与するサイトカ インついて報告されている。そこで最近、注目されている One way one disease の概念から、難治性副鼻腔炎の一つである 好酸球性副鼻腔炎について、マクロファージ、好中球とそれらの産生に関与するサイトカインを含めて検討した。方法：手 術の際、摘出したヒト慢性副鼻胿炎鼻茸を用い、マクロファージ (CD68)、好中球エラスターゼ、さらに IL-17A、IL-8 の 発現を免疫染色法にて観察した。結果：好酸球性副鼻腔炎鼻茸において CD68、IL-17A の発現が非好酸球性副鼻腔炎鼻茸 より有意に認めた。さらにCD68 と IL-17Aには有意な相関関係を認めた。尚、好中球エラスターゼ、IL-8に関しては、両 群に有意差は認めなかった。まとめ: 好酸球性副鼻腔炎組織のリモデリングには、好酸球のみならずマクロファージが関与 している可能性が示唆された。

\section{2}

\section{インスリン様成長因子一 I の脳内輸送における嗅神経の重要性}

○志賀英明 ${ }^{1}$ 、鷲山幸信 ${ }^{2}$ 、古川 仍 ${ }^{3)}$ 、天野良平 ${ }^{2)}$ 、三輪高喜 ${ }^{1)}$

金沢医科大学 耳鼻咽喉科・頭頸部外科学 ${ }^{1}$ 、金沢大学 医薬保健研究域 量子医療技術学 ${ }^{2}$ 、金沢大学 ${ }^{3}$

インスリン様成長因子-I（Insulin-like growth factor-I：IGF-I）は塩基性ペプチドで成長ホルモンを介して脳神経の発達 や成長に関わっている。脳梗塞などへの臨床応用が志向されているが、血液脳関門で脳内への取り込みが阻害されるため血 液脳関門を回避する経路として鼻腔内投与による嗅神経輸送が注目されている。これまで経鼻投与によるラット嗅神経と三 叉神経を介した IGF-I の脳内輸送が報告されている。今回われわれが ICR 健常マウスに対し I-125 標識 IGF-I 経鼻投与 したところ、脳神経中枢と嗅球への IGF-I 取り込みの用量依存的な増加を認めたのに対し、三叉神経への取り込みに投与 量による変化は認めなかった。さらに片側嗅球除去マウスの両鼻腔に対する I-125 標識 IGF-I 投与による脳神経中枢におけ る IGF-I 取り込みの左右差も評価した。IGF-I 経鼻投与による脳内輸送は主に嗅神経経由と考えられる。経鼻投与による高 分子薬物の脳機能制御作用を目的とする臨床試験対象者の選定には嗅神経輸送能の評価が重要であることが示唆された。 
133 Poly（I：C)、TNF- $\alpha 、 T h 2$ サイトカイン混合刺激による鼻線維芽細胞からの TARC 産生

○野中 学 ${ }^{1)}$ 、田中友佳子 ${ }^{1)}$ 、吉原俊雄 ${ }^{11} 、$ 酒主敦子 ${ }^{2)}$ 、Pawankar Ruby ${ }^{2)}$

東京女子医科大学 耳鼻咽喉科 ${ }^{12}$ 、日本医科大学 耳鼻咽喉科 ${ }^{2}$

【目的】喘息はウイルス感染により増悪するが、増悪因子で主役を演じるのは Th2 細胞と考えられている。喘息を合併す る慢性副鼻腔炎においても Th2 細胞の誘導が重要な役割を果たしている可能性がある。われわれは、鼻（鼻茸および健常 鼻由来）線維芽細胞を poly（I：C)、TNF- $\alpha$ 、Th2 サイトカインで刺激し、Th2 細胞の遊走因子である TARC 産生について 検討した。【方法】鼻茸扔よび健常鼻の粘膜より単離した線維芽細胞を poly（I：C）、TNF- $\alpha$ 、Th2 サイトカインの種々組 み合わせで刺激し、TARC 産生を ELISA 法と real time PCR 法により検討した。【結果】 poly（I：C)、TNF- $\alpha$ 、Th2 サイト カインの混合刺激で過剩な TARC 産生が認められた。その過剩な TARC 産生は時間依存的、poly（I：C）以外は濃度依存的 であった。【結論】気道 Th2 型炎症のウイルス感染に扔ける増悪因子として、線維芽細胞からの TARC 過剩産生が重要な役 割を果たしていることが示唆された。

\section{4 好酸球性副鼻腔炎における一酸化窒素（NO）濃度のモニタリングについて}

○野田礼彰、平川勝洋、竹野幸夫、石野岳志、福入隆史、樽谷貴之

広島大学大学院 医歯薬学総合研究科 耳鼻咽喉科・頭頸部外科

多機能分子である一酸化窒素（NO）は、一酸化窒素合成酵素（NOS）の働きでヒトの気道において豊富に産生されてお り、種々の重要な生理機能、並びに気道炎症の制御に深く関与する内因性調節因子としての評価が定まっている。そして、 副鼻腔はNO の主な発生源であり、気道の NO 濃度に大きく関与していることが報告されている。そのため、呼気 NO 濃 度が鼻副鼻腔における炎症の状態を評価する非侵襲性のマーカーになる可能性が考えられている。今回、われわれは bedfont 社（英国）製の簡易型 NO 濃度測定モニターである NObreath ${ }^{\circledR}$ を用い、好酸球副鼻腔炎症例における治療前後での 口呼気 NO 濃度、鼻呼気 NO 濃度の変化を測定した。そして、口呼気と鼻呼気 NO 濃度の測定が好酸球性副鼻腔炎の経過 を評価するのに有用であるか検討した。またNO 濃度の変化と合わせて、鼻副鼻腔粘膜での NOS アイソフォームの発現と 局在について、リアルタイム PCR および免疫染色により分析した。

\section{マウス嗅球および嗅上皮における組織型プラスミノゲンアクチベータの発現}

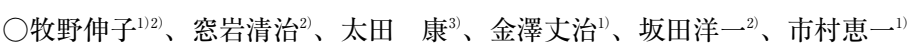

自治医科大学 耳鼻咽喉科 ${ }^{1}$ 、自治医科大学 分子病態研究センター 分子病態学 ${ }^{2}$ 、

日本赤十字社医療センター 耳鼻咽喉科 ${ }^{3}$

【はじめに】組織型プラスミノゲンアクチベータ（tPA）は血管内皮やグリア細胞で産生されるセリンプロテアーゼであ り、プラスミノゲンの活性化を介して血栓溶解や組織の再生に関与するとともに、中枢神経再生において単独作用を持つこ とが報告されている。われわれはこれまでtPAが嗅上皮の再生にも大きな役割を果たすことを報告してきた。今回 tPAの 嗅球および嗅上皮での発現について検討したので報告する。【方法】野生型マウスの嗅球および嗅上皮に扔けるtPAの発現 を、RT-PCR 法、in situ Hybridization 法を用いて検討した。結果】 RT-PCR 法により、嗅球および嗅上皮から tPAの転写 物を検出した。またin situ Hybridization 法を用いて組織学的に検討し、嗅球内では血管内皮と傍系球体細胞、嗅上皮では 上皮下の血管内皮細胞および上皮内のボーマン腺導管近傍細胞にtPAの発現が認められた。【結論】嗅球および嗅上皮に tPA が発現し、嗅上皮の再生に何らかの役割を担っている可能性が示唆された。

\section{6 慢性副鼻腔炎での NDRG1 の発現と鼻粘膜バリアにおける役割}

○岸 博行 ${ }^{12}$ 、権 寧博 ${ }^{2}$ 、野村泰之 ${ }^{1)}$ 、池田 棇

日本大学 医学部 耳鼻咽喉・頭頸部外科学分野 ${ }^{11}$ 、日本大学 医学部 内科学系 総合内科学分野 ${ }^{21}$

酸化ストレスによって誘導される N-myc down regulated gene 1(NDRG1）は、細胞の増殖や遊走に関係していることが 知られているが、粘膜上皮における役割は明らかでない。今回われわれは慢性副鼻腔患者16名より採取した副鼻腔粘膜を抗 NDRG1 抗体によって免疫染色を行った。気道上皮細胞株 16HBE 細胞の NDRG1 遺伝子を siRNAでノックダウンし、 transepithelial electric resistance(TER) とdextran 透過率（Dxi）により上皮バリア機能を測定した。NDRG1の発現量は real-time PCR で測定した。慢性副鼻腔炎患者の副鼻腔上皮における NDRG1 の発現を観察した。形態的に正常な線毛上皮 でNDRG1 の高い発現が観察されたが、傷害上皮では発現が低かった。扁平上皮化生や杯細胞過形成では NDRG1の発現が 低かった。以上より NDRG1 は正常鼻粘膜上皮の恒常性の維持に重要であることが示唆された。NDRG1は、気道粘膜上皮 におけるバリア機能に重要な役割を果たし、NDRG1の発現異常はアレルギー性炎症における鼻粘膜上皮傷害や上皮再生異 常に関係している可能性が示唆された。 